\title{
IMAGINING UTOPIA, SUSTAINING COMMUNITY Autoethnographic Research and Queer Affective Pleasure
}

Elizabeth Whitney

\begin{abstract}
For queers, the affects of pleasure and risk are intrinsically interrelated, and the practice of imagining utopia signifies the importance of community as a place where we come together to sustain and nurture ourselves. This essay explores the affective pleasure of queer worldmaking through community building in Finland from my perspective as a non-Finnish queer researcher. Taking pleasure in the freedom to experiment is at the very heart of being together, resisting heteronormativity, and visualizing alternative and utopian ways of worldmaking. While such acts are not necessarily unique to Finland, my experience as a queer feminist researcher and participant in Finnish queer communities was unique to me. Thus, I use autoethnography to discuss my insider/outsider experience of conducting research in Finland, as a queer feminist from the US My work adds to a growing body of autoethnographic scholarship that raises questions about crosscultural perception and belonging, and offers new possibilities for queer methodologies.
\end{abstract}

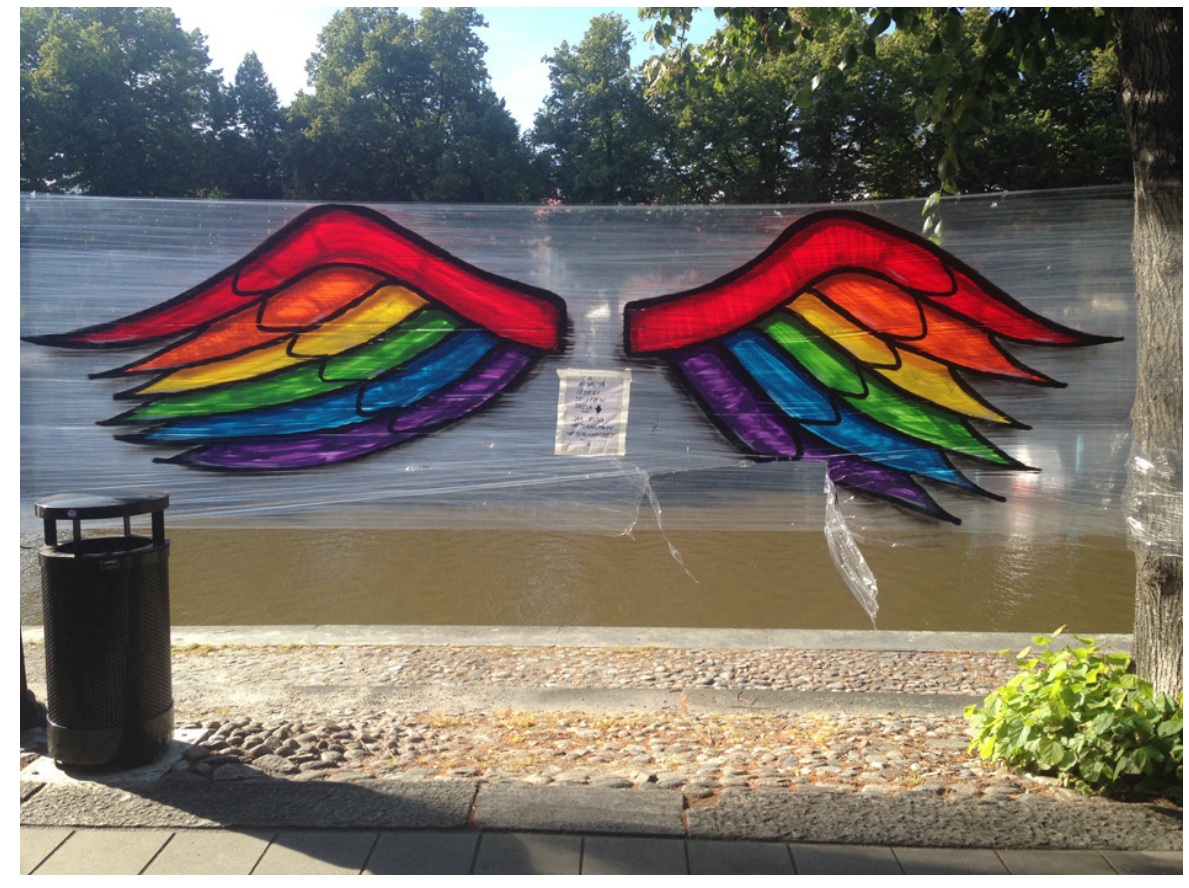

Turku Pride Wings. Image: Elizabeth Whitney. 
The hope of queer politics is that bringing us closer to others, from whom we have been barred, might also bring us to different ways of living with others... A queer hope is not, then, sentimental. It is affective precisely in the face of the persistence of forms of life that endure in the negative attachment of 'the not.'

Sara Ahmed, The Cultural Politics of Emotion (2004, 165)

\section{Introduction: Being a Queer Insider/Outsider in Finland}

After walking around the block three times, we still could not find the bar. With our devices leading the way, we tried to follow the directional map, but were quickly coming to the conclusion that it must have closed. We knew at one point there was a bar, because it had been reviewed online, and we knew it must be on this corner, but we were somehow lost.

A month later, when we walked past that corner again and saw that the bar was indeed there and open for business, we wondered how we could have possibly missed that obvious rainbow lettering?! Were our cultural interpretation skills completely obscured by the unfamiliar language? What kind of queers were we, to be so lost right in front of what should have been a signpost for locating a community? (Author's notes)

During the 2015-2016 academic year, I was a Fulbright Scholar in Finland researching arts funding and freedom of expression as a point of cultural comparison with the United States. While this research was not specifically queer, because of my own interests, I was drawn to queer and queer-friendly spaces. Thus, I observed and participated in queer worldmaking (Berlant and Warner 1998) occurring in Finland through the performance of building community (Johnson and Rivera-Servera 2016; Taylor 2012; Vogel 2000). My focus here is on the affective pleasure of both belonging and not belonging to normative society (Seigworth and Gregg 2011). Queer theorists have recently called into question the ways in which queerness hinges on claims of non-normativity (Weigman and Wilson 2016), suggesting that there might be a possibility for theorizing queerness in ways that move beyond a normative/non-normative binary. In this essay I focus on the concept of pleasure as a way to think beyond this binary, and ask how the affective pleasure of queer worldmaking through community building functions as a driving force for queers. Worldmaking is a promising concept for exploring imaginative ways of making and understanding community as a utopian space-an undetermined construct for queer possibility.

It is primarily my own search for pleasure that I am recording and interpreting. I was looking for queer community, in its multitudinous forms, and simultaneously looking for the familiar while experiencing it in an unfamiliar context. Aside from the pleasure of experiencing the (un)familiarity of queer spaces, feelings of frustration, inspiration, and disorientation were also present for me as I operated in a new cultural context. This essay is meant to function self-reflexively: a meditation on the affective pleasure, as well as the challenges of engaging in research in a cultural context that is both familiar and unfamiliar.

I employ an autoethnographic research method (Jones, Adams and Ellis 2015; Muncey 2010; Chang 2008; Ellis 2004) to frame my insider/outsider experience (Dwyer and Buckle 2009; Merriam et al. 2001; Acker 2000; Mullings 1999; Probyn 1996), from my perspective as a queer feminist from the US I use autoethnography because, as Tony Adams and Stacy Holman Jones argue, it is a queer method. Saying that autoethnography is queer is, "...taking a stand on the poetics of change. Saying so treats 
identities and communities as a performative, relational accomplishment" (Adams and Jones 2008, 385). Autoethnography makes sense of the challenges of accomplishing such relations, as in the example from my field notes of missing such obvious queer cues as a gay bar with a rainbow sign. My autoethnographic research practice included attending such events, journaling, field notes, and image documentation. As an autoethnographic researcher I am attentive to the question of ethics when representing both my own self-reflexivity as well as the ways that I represent people with whom, and spaces in which I am engaged (Barton 2011; ChathamCarpenter 2010).

In this essay, I reflect on my experience of attending various events that serve as examples of the queer labor of worldmaking and community building: my local queer bar, a house party, a feminist cursing "open mic," a brunch fundraiser for Turku Pride, and a film screening fundraiser for the Wonderlust Festival in Helsinki. All of the events I discuss in this essay were community events in public spaces. I consider how my positioning as a US-based researcher allows me to engage with queer communities in Finland differently than a Finnish researcher might, particularly with regards to the orienting cues of recognizing what I perceive to be queer interactions and queer spaces.

\section{Imagining Utopia = Sustaining Community}

I was invited to a house party in what I would call the suburbs, if I were in a US context. The invitation specified that this was a queer-friendly space, and that there would be performances, music, food, and a sauna. A friend and I took a bus to get there, as it was roughly forty-five minutes from the city center. When we exited the bus, a small group of people who had also been on board joined us - all going to the party. We walked for ten minutes through what seemed like rural land to me, and found ourselves in a house that was FULL of people in sparkling, rainbowthemed costumes that I read as queer. It was a very cold night, and the minute our group entered, everyone began removing their heavy coats to reveal that they had carefully planned their outfits. I felt boring in my black sweater and jeans, but I was welcomed just the same. Later, the friend of a friend who invited me cautioned me to remember that this was not a typical Finnish party. And yet, there I was, in the midst of a large, diverse group of queer-minded people in a quiet neighborhood in Finland. I wondered, what was a typical Finnish party, then? (Author's notes)

Finland is often represented as a utopia in left-leaning United States media, often with regards to institutional structures such as education. When I told this to a Finnish colleague who had recently returned from studying in the US, they remarked that when they explained how things are in Finland, it sounded utopian even to them. Films like David Guggenheim's Waiting for Superman and Michael Moore's Where to Invade Next tout Finland's public education system as a global model. The point of these documentaries is to create productive possibility in the US by imagining better models of educational practice. So why not imagine Finland as a queer utopia as well as an educational one?

Utopia has been commonly theorized as a no place (Foucault 1986), or a space of possibility rather than actuality (Muñoz 2009). To imagine the possibility of utopia is key to queer worldmaking. To experiment in changing our lived experience is also key to community sustainability and survival as well as a crucial part of materializing utopian spaces. Without our imaginations, we have only the actual, which is often one-dimensional and uninspiring, if not sometimes downright depressing. We imagine in order to create potentiality, and alternative ways of existing. In other words, the act of imagining utopia is radical and necessary for queer communities. 
The possibility of imagining Finland as a queer utopia is one I have raised with various collaborators and colleagues, and has been met with both interest and concern. Perhaps this is because the possibility of utopia creates the possibility of disappointment, or perhaps this is because of the ways in which Finland is struggling with increasing financial austerity and political conservatism. I recognize that my position as a cultural outsider makes it easier to take the risk of imagining Finland as a queer utopia, though I am intrigued by the use value of this exercise. Like Adele Pavlidis (2013) in her autoethnographic research on participating in roller derby, I am interested in considering the meaningfulness of my marginality as a cultural outsider. The duality of being an insider as a queer feminist, and an outsider as non-Finnish, allows me to critically reflect on my subjectivity as a participant-observer ethnographer, and complicates the affective politics of queer community building in Finland.

Imagining a queer utopia anywhere is a challenge. In the face of street harassment, violence, protest, and discriminatory legislation, we are required to think, or fantasize, beyond the present moment if we want to dream of an alternative. We are challenged to think, "if not this, then what?" as Tuula Juvonen and Pia Livia Hekanaho (2008) do in considering the possibilities for queer studies in Finland. We must engage in possibility and utopian thinking as exercises in considering what might otherwise seem impossible. In his article in a previous issue of SQS, Piotr Sobolczyk $(2015,1)$ asks, "How utopian must one be to think of a queer planet?" Sobolczyk is asking us about the limits of our imaginations. He is asking us if we can imagine the impossible.

For queers, the affects of pleasure and fear that accompany risk-taking are intrinsically interrelated. Finding pleasure in the freedom to experiment is at the very heart of resisting and existing within heteronormativity: we are practiced at performatively visualizing alternative and utopian ways of worldmaking through the processes of building community. Exercising utopian imagination frees queer communities from heteronormative expectations and proscribed ways of being. Utopian thinking signifies community as a place where queers come together to creatively invent ourselves in self-sustaining and nurturing ways, and are thus dependent upon and actively fostering investment in futurity (Muñoz 2009).

Queer theorists and activists are constantly engaged in the labor of nonreproductive (re)production. The question of the future - or, to use Jose Esteban Muñoz's term, futurity - is one which demands a commitment to possibilities and sustainable practices of existence. In the introduction to the anthology Queer Futures: Reconsidering Ethics, Activism, and the Political (2013) the editors re-frame Michael Warner's (2012) controversial suggestion that queer theory is ending. Instead, the editors ponder, “... queer's iterative capacity which yields the power of self-renewal” (Yekani, Kilian and Michaelis 2013, 31). Queer communities invest in futurity through constant and imaginative reiteration, in ways that challenge, or, reimagine, normative concepts such as time (Love 2009; Halberstam 2005). We (re)produce our futurity when we are unafraid to imagine ourselves out of and/or against heteronormative time and place.

Themes of risk-taking and intervention, development and pleasure, and a commitment to futurity, are central to the question of the queer utopian imagination. Queer communities challenge homogenous ideologies through the counterhegemonic practice of queering experience. Our insistence on public visibility and determination to show up and enjoy ourselves pushes back against normative social expectations. On social media, in our lived interactions, and at community events, we are actively working to imagine utopia by engaging in hope and pleasure as affective markers of our existence as queers. In Finland, I witnessed the persistence of queer vitality, and effective methods of challenging cultural homogeneity and normativity.
SQS

$1-2 / 2016$

Queer Mirror Essay

Elizabeth Whitney 


\section{Live Events: Community Building in Action}

The roller derby bout was packed with people of all ages carrying signs for teams and players. It was the first time we had seen so many queers in one space! From the merch table where a femme with pink hair offered $T$-shirts, to the young trans-masculine person explaining the rules of the game alternating between English and Suomi, we were thrilled to be surrounded by queers and their families and allies.

A drag queen who was an emcee counted down in Suomi - numbers we were already beginning to recognize. It was a long bout, and her heels were high, so by the break she was seated on the floor while commenting on the action. While we didn't understand what she was saying, her playful humor was familiar enough (Author's notes).

While it is true that most people in Finland speak at least some English, they generally do not speak it to each other. Most of the events I attended took place in Suomi, and even if they did take place partly in English, the conversations happening around me were mostly unintelligible to me. While I worked to learn basic phrases and vocabulary, I was far from fluent in Suomi, and this presented a constant challenge in my research, as well as my daily existence. As Sara Ahmed $(2006,11)$ notes in Queer Phenomenology, "the work of inhabitance involves orientation devices...". The experience of being surrounded by a language I did not understand or speak was indeed phenomenologically queer, and encouraged me, with an affective force, to focus on the things I could understand about the events that were outside of spoken or written texts - my lived experience of being there. While pragmatics necessitated that I look for orientation devices on social networking platforms and awkward website auto translations, more often I was oriented by fashion cues, eye contact, generous introductions from friends and colleagues, and other queer and feminist exchanges.
Returning again to Sara Ahmed's (2004) work in The Cultural Politics of Emotion, she observes that "queer bodies 'gather' in spaces, through the pleasure of opening up to other bodies. These queer gatherings involve forms of activism; ways of claiming back the street, as well as the spaces of clubs, bars, parks and homes" (Ahmed 2004, 165). Ahmed's argument for queer gathering as a pleasurable endeavor is central to my observations of the events I am writing about in this section. Activist gathering involves multiple forms of labor, perhaps most important, emotional labor - and queer emotional labor is always an investment in the possibility and sustainability of community (Cowan and Rault 2014). Here, I consider the affective pleasure of queer activist labor.

Queer space is precious and hard won - particularly public spaces where queerness is allowed and encouraged. The diverse range of events I am discussing here raises important questions about what, exactly, makes a space queer - or, at least, how I thought that I was recognizing queer space. My partner and I sometimes found ourselves in spaces in Finland that were not defined by any formal sign, yet felt markedly queer. What makes a space queer, then? While material markers and assembled bodies certainly contribute to - and, alternately, challenge, as in Jasmir Puar's work $(2005 ; 2007)$ - formations of queerness, understanding a space as queer has so much to do with experiential perspective. All this is to say that I am acutely aware of how my perception of queerness in Finnish public spaces and events is obviously shaped by my US worldview and a certain way I believe that I have of recognizing queerness.

\section{Event 1: Feminist Cursing}

The small bar was packed with hip, young people - mostly women, and many of whom I read as queer based on intimate behaviors and aesthetic style. A woman at a sofa near the back wore bright red lipstick and a

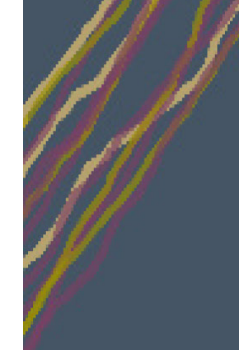


T-shirt that said, "good girls go to heaven, bad girls go to Lapland." This was just about the only thing I saw or heard in English the entire evening (Author's notes).

After having been in Finland for about a month, my partner and I were invited to what I would call an "open mic." This was one of my first windows into the vibrancy and activism of Finnish queer feminist communities. The event was called "Feministinen Kiroiluiltama," and, like many Suomi expressions, it has no direct translation into English - though a possible explanation would be something like "a public feminist consciousness raising event where people can curse in both politicized and entertaining ways." Participation was open to anyone who wanted to get up and share a story, poem, song, or other narrative that involved as much cursing as possible.

Since I have already identified myself as a queer feminist researcher, my interest in attending an evening of feminist cursing might be obvious, as well as my desire for a community that is both queer and feminist. The crowd at this event was, from the shared perspective of myself and my partner, undeniably queer. Were we, in fact, in a room full of badass queer femme women and their gender non-conforming compatriots who were engaging in public cursing as an act of resisting gender norms? Both my partner and I agreed that we were indeed surrounded by queer feminists, although of course the possibility exists that our utopian imaginations were already fully engaged. Still, there were orienting clues: overly friendly eye contact, a meaningful smile, offers of a place to sit. Though the atmosphere was invitational, this was a markedly insider/outsider event for us. It was an insider experience because we recognized the queer community all around us, and we also felt recognized as queers. However, it was also an outsider event because of the language barrier. It is indeed a very queer experience to be surrounded by your chosen community while simultaneously immersed in an unfamiliar language.

Fortunately, we had recently learned the very important curse word "vittu," which technically translates as "cunt," although it is used in a general way like people in the US might use "fuck." The reason we knew this word was that a queer feminist colleague and friend had, just a week before, explained to us the complex and controversial feminist history surrounding this word. It comes from Finnish-Karelian folk traditions of women's magic and vaginal power (Stark-Arola 1997), though it has been diffused as part of common vernacular. However, Finnish queer feminists continue to be aware of and rehistoricize the power of the term in its origins. Like all Finnish nouns, there are seemingly endless ways to conjugate the word $v i t t u$. We heard many of them on that night, and tried to recognize as many forms as possible: vitun, $j$ a vitut, voi vittu, vittuilla, vittujen, etc. I have since heard vittu being used by people cursing on the street, and each time, I think of the affective power of hearing so many feminists and queer feminists using it that night at the open mic.

This event of course required organizational and emotional labor. In this case, there was a Facebook invitation, and a negotiated space with the bar where the open mic took place. The organizers of this event are also the creators and facilitators of Hattu: A Feminist Think Tank, which operates out of Tampere and was founded in 2015. Hattu's website states their mission as follows:

Hattu offers carefully crafted feminist analysis and insights on anything, really. We can produce academic and popular texts, artworks and visual commentaries, and oral presentations. We promote laughter and are working on a theory of radical fun.

We can organize, for example, emancipatory seminars, cursing 
events, how to be funny workshops, collaging tutorials, lectures on feminist politics, courses on popular culture and world politics (Hattu website 2016).

Hattu's statement emphasizes the importance of play and fun as pleasurable engagement, and their relationship to critical analysis. Cursing, in this case, is more than an act of public taboo; it is an expression of the affective pleasure of doing activist work.

\section{Event 2: Film Screening for Wonderlust}

The room for the screening was covered in pillows and crowded with a multi-gendered crowd. People lounged throughout the room on the various types of pillows, comfortable expressing intimacies that seemed both romantic and platonic. When my friend and I walked in, someone thoughtfully brought us chairs, although in my mind, I worried that I looked like I wasn't hip enough for a pillow (Author's notes).

The pleasure to be found in a public indulgence of taboo is at the center of the Wonderlust festival that takes place in Helsinki every June. Advertised as "a festival celebrating diverse and conscious sexuality," Wonderlust exists because of a concern that "first hand pleasure is becoming increasingly rare" (Wonderlust website 2016). Resisting the trend toward virtual pleasure, Wonderlust provides an opportunity to engage in the pleasure of live interaction with other sex-positive, queer-minded people.

I attended a fundraiser for Wonderlust last fall in Helsinki with a Finnish friend. At the fundraiser, the festival organizers screened Buck Angel's documentary, Sexing the Transman. In this film, Angel "elicits intimate, in-depth conversations with transmen and those who love them - about how their bodies, sexualities, and identities are affected by the medical and social processes of gender transition" (Sexing the Transman website 2016). The film was screened at a building in Suvilahti, an industrial area reclaimed as arts spaces. On the second floor of one of the buildings is a space shared by multiple arts organizations.

Watching transmen have sex on film in such close quarters was surprisingly publicly intimate. I have attended events with a similar vibe in the US, so the only surprising part (to me) was that it occurred in Finland. This was largely due to the (stereotypical) expectations I had of Finland as socially and sexually reserved - and yet here was a room full of queers and allies lounging together on pillows, watching a documentary by a porn star. I seemed to keep finding these spaces that were supposedly anomalous to Finnish culture. Of course, it was my mistake to import a US reading of public pornography viewing to a Finnish context. In fact, encountering an article in Vice Magazine about a queer feminist porn magazine Ménage à trois in Finland (Babišová and Hooker 2014) was one of the motivating factors for applying for my Fulbright so I am still surprised that I was so surprised by this event. As Susanna Paasonen (2009) argues regarding histories of porn in Finland, the dialogue on pornography here has not been shaped by the sex wars as the dialogue in the US has. While queer and feminist views on pornography in Finland are certainly complicated, anti-porn sentiment has not become the "iconic issue" here that it has in the US (Paasonen 2009, 588).

There was a moment during Sexing the Transman when my colleague and friend, with whom I was attending, made me laugh out loud. The film includes interviews with US comedian Margaret Cho, who positions herself as a trans ally. Since the politics of penetration are central to this documentary, during one of the interviews, Angel asks Cho if she had ever penetrated a trans man. Cho replies by saying that she is a bottom, and she
Queer Mirror Essay 
doesn't think about penetrating anyone. At this point, my friend turned to me and said, 'then maybe she should think about it.' A humorous moment, to be sure, and also one that was markedly insider for me as a researcher. I laughed at my friend's comment out of acknowledgement. In a moment of queer recognition, we shared our desire to subvert Cho's stereotypical representation of queer femmes.

\section{Event 3: Brunch Fundraiser for Turku Pride}

On the riverwalk in Turku we saw a large banner that depicted rainbow angel wings stretched across clear plastic of some sort. The banner was designed so that a person could stand in front of it, stretch out their arms, and appear to be wearing the wings. On the bottom right corner there was a small tear. Each time we passed the banner the tear was more pronounced, and it was the first time I saw public evidence of anti-queer sentiment (Author's notes).

Turku Pride takes place in August, and like the Wonderlust event I attended, there are fundraisers throughout the year to support the annual event. On a cool and sunny day in June, my partner and I attended a vegan brunch at Kirjakahvila. This bookstore café, located near the University of Turku, is known for being a gathering place for the queer and feminist community. The café is open to multiple organizations to host events whichever organization is hosting uses the kitchen to cook the food they are serving. It's a small place, and we sat at tables outside. When they ran out of food halfway through the brunch, a friend remarked, "they always run out of food." There were a lot of people at the brunch, so it's no surprise that supplies were running low, although the delicious caramel-like cake they served was fortunately replenished long after the sautéed seitan and mushroom salad were gone.
The amount for brunch was charged on a sliding scale - a hallmark of queer community events. We could choose to pay between ten and fifteen euros, depending on our level of income. The brunch, like most buffet meals I've had in Finland, came with tea, coffee, and dessert - the delicious cake. The crowd was, like those at the other events I attended, mostly in their 20s and 30 s, mostly white, and many were wearing cultural markers of queer identity (rainbow attire, multicolored hair, piercings, political patches and pins).

The Turku Pride website was only published in Suomi, and my auto translate provided a poor reading in English. In fact, translations from Suomi to English were consistently poor in my experience, providing only a rudimentary understanding of the original ideas - no fault of the translation machinery here, but rather, indicative of the linguistic complexity of Suomi that takes years to fully understand. Nevertheless, auto translate was indispensable for me in gaining at least a general idea of what was going on. I turn, here, to my automatic translation of the Turku Pride website to provide an illustration of the complications of doing research in a language which I was not able to learn as quickly as I would have liked. Here is the translation my computer provided me for the call for volunteers:

Turku Prideä made together, a large number of volunteer efforts! Would you just come to ensure that the traffic is during the parade? Or do you perhaps vigilante qualifications? Give a couple of hours a day a Pride-27.8 and join in! (Turku Pride website)

Vigilante qualifications, while a seemingly strange choice of words for auto translation, are a powerful concept for queer communities. Pride is a necessary engagement in pleasure and an affirmation of existence - a vigilante act in the face of heteronormativity. While this translation, in some ways, marks me as an outsider because of language, the queer pride I experienced in participating in the brunch fundraiser is most certainly a moment of insider recognition. 


\section{Conclusion: The Value of Queer Affective Pleasure in Finland}

Shortly after attending the Turku Pride brunch fundraiser in the spring of 2016, I opened my laptop to see the news of a mass shooting at a crowded nightclub in Orlando, Florida. Forty-nine people were murdered by a man with an automatic weapon who had reportedly previously frequented the club. They were murdered while dancing. Survivors said that initially they thought the sound of gunfire was part of the music. I thought of all of the dance clubs I had been to during my twenties and imagined the horror of being shot down in a moment of shared community pleasure. (Author's notes).

What does utopia look like? Perhaps it is a crowded nightclub where, as Ahmed (2004, 165) suggests, "Queer pleasures put bodies into contact that have been kept apart by the scripts of compulsory heterosexuality". But what if that nightclub is interrupted by the violence of compulsory heterosexuality, in the form of an angry man with an assault rifle? The timing of the violence at the US nightclub in Orlando, Florida was a prescient reminder for me during my research that queer utopian spaces are ephemeral, and that the work of sustaining them is a necessary labor.

Yet, even in the face of violent possibilities, we continue to go to the nightclub, the bookstore, the film, the café, and the parade. In defiance of the violence of heteronormativity, queer communities are co-creating cultural potentialities that offer a glimpse at something beyond our immediate moment. In their article, "Pleasure: An Initial Exploration," Biswas et al. $(2015,315)$ write, "social pleasures arise from social interactions, activity pleasures from the process of enjoying an activity rather than the end result...”. Pleasure in the performance of queer community at the three events I have discussed here was predicated on my experience of participation. The act of engagement not only created the affect of pleasure, the act itself was the pleasure. Participating in these queer community events was an act of pleasurable imagination; visualizing Finland as a queer utopia.

As I write these final paragraphs, I am in mourning over both mundane and acute occurrences of the violence of heteronormativity. At the same time, like so many queers, I am unwilling to allow such violence to stop my engagement in a utopian imaginary. This queer autoethnography is part of my unwillingness, as well as part of my commitment to international scholarship between my now queer Finnish and US worlds. In the words of editors Kaisa Ilmonen and Tuula Juvonen $(2014,5)$, “... Finnish queer studies is alive and kicking. It does not narrate itself in a single voice but reaches out thematically, methodologically and theoretically in new directions while also reconsidering the past. It queers both the politics of remembering and the preconditions of traditions". My research means to contribute to these new directions, affectively queering future possibilities for international work.

In moments when I was aware of my position as a cultural outsider in Finland, I was grateful for the powerful experiences with queer community that my research has allowed me. And, in moments of awareness of being a queer insider in Finland, I was appreciative of the ways in which community can function across cultural identity, when we make spaces inclusive. Community events can make worlds, like the ones I attended in Finland, and they can also threaten to unmake them, like the Pulse nightclub massacre in the US However, queer community is resilient and insistent in engaging in affective pleasure and imagination. The pleasure we gain from engagement sustains us through the pain of disappointment, loss, and violence. And so, I continue to have hope for queer utopian spaces, and appreciate the ways in which engaging in research in Finland has showed me new possibilities for understanding community. 


\section{References}

Acker, Sandra. 2000. "In/out/side: Positioning the Researcher in Feminis Qualitative Research.” Resources for Feminist Research 28(1-2): 189208.

Adams, Tony E., and Stacy Holman Jones. 2008. “Autoethnography is Queer.” In Handbook of Critical and Indigenous Methodologies, edited by Norman K. Denzin, Yvonna S. Lincoln, and Linda Tuhiwai Smith, 373-390. Thousand Oaks, CA: Sage Publications. https://doi.org/10.4135/9781483385686. n18

Ahmed, Sara. 2004. The Cultural Politics of Emotion. New York: Routledge.

Ahmed, Sara. 2006. Queer Phenomenology: Orientations, Objects, \& Others. Durham: Duke University Press. https://doi.org/10.1215/9780822388074

Babišová, Martina, and George Hooker. 2014. "Finally, There’s a Queer Feminist Porn Magazine Available in Finland." Vice Magazine, April 29. Accessed August 28, 2016. https://www.vice.com/sv/article/menage-a-trois-isputting-porn-in-feminism-finland.

Berlant, Lauren, and Michael Warner. 1998. "Sex in Public." Critical Inquiry 24(2): 547-566. https://doi.org/10.1086/448884

Bernadette, Barton. 2011. "My Auto/Ethnographic Dilemma: Who Owns the Story?" Qualitative Sociology 34(3): 431-445.

Biswas-Diener, Robert, P. Alex Linley, Helen Dovey, John Maltby, Robert Hurling, Joy Wilkinson, and Nadezhda Lyubchik. 2015. "Pleasure: An Initial Exploration.” Journal of Happiness Studies 16(2): 313-332. https:// doi.org/10.1007/s10902-014-9511-x

Chang, Heewon. 2008. Autoethnography as method. Walnut Creek, CA: Left Coast Press.

Chatham-Carpenter, April. 2010. "Do Thyself No Harm: Protecting Ourselves as Autoethnographers." Journal of Research Practice 6(1): 1-13.

Cowan, T.L., and Jasmine Rault. 2014. "The Labour of Being Studied in a Free Love Economy." Ephemera: Theory and Politics in Organization 14(3): 471-488. Accessed June 6, 2016. http://www.ephemerajournal.org/ contribution/labour-being-studied-free-love-economy.

Dwyer, Sonya Corbin, and Jennifer L. Buckle. 2009. "The Space Between: On Being an Insider-Outsider in Qualitative Research." International Journal of Qualitative Methods 8(1): 54-63. https://doi. org/10.1177/160940690900800105
Ellis, Carolyn. 2004. The Ethnographic I: A Methodological Novel About Autoethnography. Walnut Creek, CA: AltaMira.

Foucault, Michael. 1986. "Of Other Spaces: Utopias and Heterotopias.” Diacritics 16(1): 22-27. https://doi.org/10.2307/464648

Halberstam, Jack. 2005. In a Queer Time and Place: Transgender Bodies, Subcultural Lives. New York: NYU Press.

Hattu: A Feminist Think Tank. 2016. Accessed June 6, 2016. http://www. hautomohattu.fi/in-english/.

Ilmonen, Kaisa and Tuula Juvonen. 2014. "Queer Traditions: Politics of Remembering." SQS Journal 8(1-2): 1-5.

Johnson, E. Patrick, and Ramón H. Rivera-Servera, eds. 2016. Blacktino Queer Performance. Durham: Duke University Press.

Jones, Stacey Holman, Tony E. Adams, and Carolyn Ellis, eds. 2015. The Handbook of Autoethnography. New York: Routledge.

Juvonen, Tuula, and Livia Hekanaho. 2008. "Leaving a Glorious Future Behind? Queer in the Finnish Academia.” Trickster \#2. Accessed June 6, 2016. http://rikster.net/2/juvonenhekanaho/5.html.

Love, Heather. 2009. Feeling Backward: Loss and the Politics of Queer History. Cambridge: Harvard University Press.

Merriam, Sharan B., Juanita Johnson-Bailey, Ming-Yeh Lee, Youngwha Kee, Gabo Ntseane, and Mazanah Muhamad. 2001. "Power and Positionality: Negotiating Insider/Outsider Status Within and Across Cultures." International Journal of Lifelong Education 20(5): 405-416. https://doi. org/10.1080/02601370120490

Mullings, Beverly. 1999. "Insider or Outsider, Both or Neither: Some Dilemmas of Interviewing in a Crosscultural Setting." Geoforum 30(4): 337-350. https://doi.org/10.1016/S0016-7185(99)00025-1

Muncey, T. 2010. Creating Autoethnographies. Thousand Oaks, CA: Sage Publications.

Muñoz, Jose Esteban. 2009. Cruising Utopia: The Then and There of Queer Futurity. New York: New York University Press.

Paasonen, Susanna. 2009. "Healthy Sex And Pop Porn: Pornography, Feminism And The Finnish Context." Sexualities 12(5): 586-604. https://doi. org/10.1177/1363460709340369

Pavlidis, Adele. 2013. "Writing Resistance in Roller Derby: Making the Case for Auto/Ethnographic Writing in Feminist Leisure Research." Journal of Leisure Research 45(5): 661-676. https://doi.org/10.18666/jlr-2013$\mathrm{v} 45-\mathrm{i} 5-4368$
SQS

$1-2 / 2016$

Queer Mirror Essay

Elizabeth Whitney 
Puar, Jasbir. 2005. "Queer Times, Queer Assemblages.” Social Text 23(3-4/8485): $121-139$.

Puar, Jasbir. 2007. Terrorist Assemblages: Homonationalism in Queer Times. Durham, NC: Duke University Press. https://doi. org/10.1215/9780822390442

Probyn, Elspeth. 1996. Outside Belongings. London: Routledge.

Seigworth, Gregory J., and Melissa Gregg. 2011. "An Inventory of Shimmers." In The Affect Theory Reader, edited by Melissa Gregg and Gregory J. Seigworth, 1-25. Durham: Duke University Press.

Sexing the Transman. 2011. Directed by Buck Angel. Buck Angel Entertainment. Accessed June 6, 2016. http://www.sexingthetransman.com.

Sobolczyk, Piotr. 2015. "Towards a Subversive Queer Atopia: Beyond the Utopia/ Dystopia Inversion." SQS Journal 9(1-2): 1-14.

Stark-Arola, Laura. 1997. "Lemi, Fire, and Female Väki: An Exploration into Dynamistic Relationships in Finnish-Karelian Magic and Folk Belief." Elektroloristi 4(1). Accessed August 28, 2016. http://www.elore.fi/ arkisto/1_97/sta197.html.

Taylor, Jodie. 2012. Playing it Queer: Popular Music, Identity and Queer Worldmaking. Berlin: Peter Lang. https://doi.org/10.3726/978-3-03510420-2

Turku Pride. 2016. Accessed June 6, 2016. http://www.turkupride.fi.

Vogel, Shane. 2000. "Where Are We Now? Queer Worldmaking and Cabaret Performance." 6(1): 29-60.

Warner, Michael. 2012. "Queer \& Then?" Chronicle of Higher Education. Accessed August 28, 2016. http://www.chronicle.com/article/ QueerThen-/130161/.

Waiting for Superman. 2010. Directed by David Guggenheim. Participant Media, Walden Media, and Electric Kinney Films.

Weigman, Robyn, and Elizabeth Wilson. 2015. “Introduction: Antinormativity's Queer Conventions." Differences: A Journal of Feminist Cultural Studies 26(1): 1-25. https://doi.org/10.1215/10407391-2880582

Where to Invade Next. 2015. Directed by Michael Moore. Dog Eat Dog Films.

Wonderlust-festival. 2016. Accessed June 6, 2016. http://www.wonderlust.fi

Yekani, Elahe Haschemi, Eveline Kilian, and Beatrice Michaelis. 2013. Queer Futures: Reconsidering Ethics, Activism, and the Political. New York: Routledge. 